\title{
Sustainable Reporting as Important Tool of Responsible Behaviour towards Stakeholders in Conditions of Slovak Food Industry
}

\author{
Mária Holienčinová, L’udmila Nagyová \\ Slovak University of Agriculture in Nitra, \\ Tr. A. Hlinku 2, 94976 Nitra, Slovak Republic \\ maria.holiencinovalgmail.com \\ ludmilanagyova@hotmail.com
}

\begin{abstract}
An important part of CSR is active informing the public about all marketing activities that company performs. This issue as part of responsible company behaviour is particularly important in the area of food sector, as these companies are directly or indirectly involved in the production and sale of food products to final customers and provide nutrition of the population. Among the experts prevails the opinion that idea that CSR can afford only strong and rich multinational companies is already overcome because CSR is perceived in a wider context (pillars CSR), which ultimately mean for businesses more savings than just the additional costs. The aim of this paper is to determine the extent up to which different sized Slovak food manufacturing companies apply sustainable reporting to their stakeholders in the conditions of Slovak food industry. Part of the paper is to determine the key stakeholders, to whom the communication should be targeted. To fulfill the aim of this paper, marketing research was conducted (a total of 120 food companies were involved). The results showed that there are significant differences between different sizes of enterprises (micro, small and medium-sized, large) in the area of reporting towards stakeholders.
\end{abstract}

Keywords: reporting, stakeholders, sustainability, food company

\section{Introduction}

The issue of stakeholders is a key part of the concept of corporate social responsibility (CSR). The application of the concept of CSR is basically building of relations and trust between the company and the individual groups. They are either directly or vicariously involved in the development of the organization [1]. Business organization today, particularly the modern corporation is currently made up of many people with many interests, expectations and demands [2]. Even in times of recession, members of the surrounding society expect quality and sustainable lifestyle. Companies must respond to individuals and groups that are entitled to create pressure and demands [3]. The challenge to the sustainability and the new role of business in society and increased expectations and new rules and tactics, management is required 
to come into contact with the main stakeholders in the area of corporate responsibility, global versus regional and local needs, and different national cultures $[4,5]$. Inclusion of stakeholders into its strategies is the key to success of organization in the 21 st century [6].

Because the stakeholders are an important part of corporate responsibility, the company will not only focus on its values and principles but will try first of all to understand the expectations of those who have an impact on business and are influenced by it [7]. Involving of stakeholders brings certain advantages:

- setting objectives and monitoring performance - setting realistic goals and evaluating the actual performance,

- innovative environment - anticipating new trends, allowing to adapt to the difficult business environment and in advance to set new strategic objectives with respect to market development,

- risk management - communication with external subjects can early identify potential risks, especially if the company will build relationships with individuals/groups who perceive the company negatively.

- information value - good and strong relationships with stakeholders mean for organization the source of valuable information [8].

\subsection{Dialogue with Stakeholders}

Company creates a certain system through which can obtain a list of potential stakeholders and based on individual activities of business can identify their sphere of interest $[9,10]$. Each organization has a different circle of stakeholders. The primary step in the implementation of CSR should be the identification, analysis and continuous dialogue with all stakeholders. To key groups should be given special attention in the issue of CSR. The following Figure 1 provides a way how to identify the key stakeholder groups.

\begin{tabular}{|c|c|c|c|}
\hline \multirow{4}{*}{ 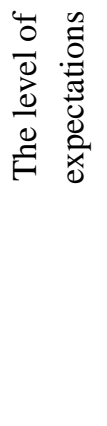 } & High & Average informing & Have a dialogue \\
\hline & Low & Answer the questions & Ensure the satisfaction \\
\hline & & Low & High \\
\hline & & \multicolumn{2}{|c|}{$\begin{array}{l}\text { The level of } \\
\text { uence on company }\end{array}$} \\
\hline
\end{tabular}

Fig. 1. Stakeholder matrix [11]

Leadership of effective dialogues of company with stakeholders is a very complex process that requires a high degree of readiness and precision. It signals the openness and interest of company of its surroundings and helps to bridge the mutual distrust. Properly conducted dialogues lead to mutual partnerships between the private, public 
and civil sector, so-called cross - sector relationship [12]. One of possible positive results of the dialogue with stakeholders is for example dissemination of good practices, mutual inspiration and motivation. Very noticeably, this aspect can be seen in the area of supplier - customer relations. If the customer is an enterprise with high profile of corporate social responsibility and the same standards will also require from its suppliers, it is a direct and very effective way to spread the principles of CSR [13].

Clear and open communication about sustainability requires a globally shared framework of concepts, consistent language and scheme. The mission of an independent institution of the Global Reporting Initiative (GRI) is to meet this need by providing credible and trusted reporting framework [14].

GRI Reporting Framework (Fig. 2) is intended to serve as a generally accepted framework for reporting on organization's economic, environmental and social performance. It is designed for use by organizations of any size, sectors, or location. It takes into account the practical considerations faced by a diverse range of organizations - from small enterprises to those with extensive and geographically dispersed operations [15].

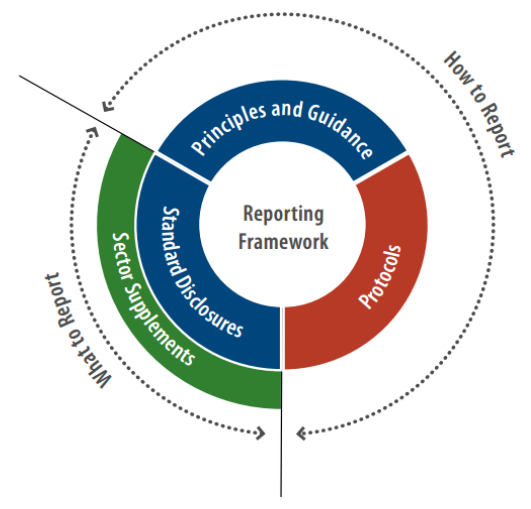

Fig. 2. GRI Reporting Framework [15]

\section{Material and Methodology}

The aim of this paper is to determine the extent up to which different sized Slovak food manufacturing companies apply sustainable reporting to their stakeholders as an important component of the CSR strategy in the conditions of Slovak food industry. The paper refers to key stakeholders from the perspective of food companies and incorporation of annual/special reports about responsible marketing activities in company guidelines. Furthermore, in our research, we want to point out on main differences between different size groups of companies connected with the area of stakeholders and reporting as a positive contribution between the society and company itself.

In order to fulfill the defined objective of the paper were collected and used primary and secondary sources of information. Underlying secondary data were 
obtained from available literature sources, i.e. from professional book publications from domestic and foreign authors and organizations. When processing of individual underlying data and formulating conclusions of the paper were used methods of analysis, synthesis, induction, deduction and the comparative method.

In order to meet the objectives of the paper, marketing research was realized. Marketing research was realized in the year 2015-2016 by the method of interview using a questionnaire. The research was focused directly on food manufacturing companies in Slovakia. The research involved 120 randomly selected food companies (totally 23 micro companies, 86 small and medium-sized companies / SMCs, 11 large companies).

Individual companies were classified by size according to excerpt from article 2 of the Annex of Recommendation 361/2003 / EC (Table 1).

Table 1. Classification of companies [16]

\begin{tabular}{|c|c|c|c|c|}
\hline Company category & Staff headcount & Turnover & or & Balance sheet total \\
\hline Micro & $<10$ & $\leq € 2$ mil. & & $\leq € 2 \mathrm{mil}$ \\
\hline Small & $<50$ & $\leq € 10$ mil. & & $\leq € 10$ mil. \\
\hline Medium-sized & $<250$ & $\leq € 50$ mil. & & $\leq € 43$ mil. \\
\hline Large & $>250$ & $>€ 50$ mil. & & $>€ 43$ mil. \\
\hline
\end{tabular}

For a deeper analysis of the obtained results, there were set out two assumptions about the dependence resp. independence between tested variables. To test the formulated dependences, there were used Friedman test, non-parametric test of contrasts that uses Nemenyi method and Fisher exact test.

\section{Results and Discussion}

Primary data for meet the objectives of the paper were obtained through marketing research, which was attended by 120 food manufacturing companies in Slovakia.

Through the following question, companies were asked to assign to their stakeholders the importance of influence (power), with regard to their marketing activities. We set out an assumption: There are differences in the importance of influence of different stakeholder groups from the perspective of food companies.

By using Friedman test was analyzed the importance of influence of stakeholders, the results are shown in Table 2. Based on the theoretical level of significance, which was compared with a significance level of alpha $=0.05$, the $\mathrm{H}_{0}$ hypothesis of the absence of differences in the importance of stakeholder influence was rejected. Based on these facts, we can conclude that there are statistically significant differences in the importance of stakeholder influence from the view of companies in consideration of marketing activities.

Table 2. Results of Friedman test

\begin{tabular}{l}
\hline Friedman's test: \\
\hline Q (Observed value)
\end{tabular}




\begin{tabular}{lr}
$\mathrm{Q}$ (Critical value) & 19,6751 \\
$\mathrm{DF}$ & 11 \\
p-value (Two-tailed) & $<0,0001$ \\
alpha & 0,05 \\
\hline
\end{tabular}

Source: Own processing, XLStat

More detailed information is available in Table 3, which shows the results of nonparametric test of contrasts that uses Nemenyi method. The various stakeholders were sorted into eight groups of at least important influence (A) to the strongest influence $(\mathrm{H})$, who were marked by individual food companies with respect to their marketing activities.

Table 3. Results of Nemenyi test

\begin{tabular}{l|llllllll}
\hline Categories & \multicolumn{10}{c}{ Groups } \\
\hline NGOs & A & & & & & & \\
State, governmental institutions & A & B & & & & & \\
Creditors & A & B & & & & & & \\
Media & & B & C & & & & & \\
Investors & & C & D & & & & \\
Surrounding community & & & & D & E & & & \\
Suppliers & & & D & E & F & & \\
Employees & & & & E & F & & \\
Competition & & & & & F & G & \\
Management & & & & & & G & H \\
Customers & & & & & & & & H \\
Company owners & & & & & & & & H \\
\hline
\end{tabular}

Source: Own research and processing, XLStat

For the best graphical representation of mentioned facts, we decided to put in a graph (Fig. 3) a modal value - mode, the value of quantitative trait of statistical series, which has the highest relative frequency, what means that occurs most frequently. Companies were asked to indicate with 5 point scale $(5 \mathrm{max} .-1 \mathrm{~min}$. importance) the most important stakeholders. The results show that the highest value $(5-\max$. importance) achieved company owners followed by customers, competition, management, employees, suppliers and the surrounding community. The lower values of importance (closer to 1) were attributed to stakeholders as state/governmental institutions, creditors, investors, media and NGOs. 


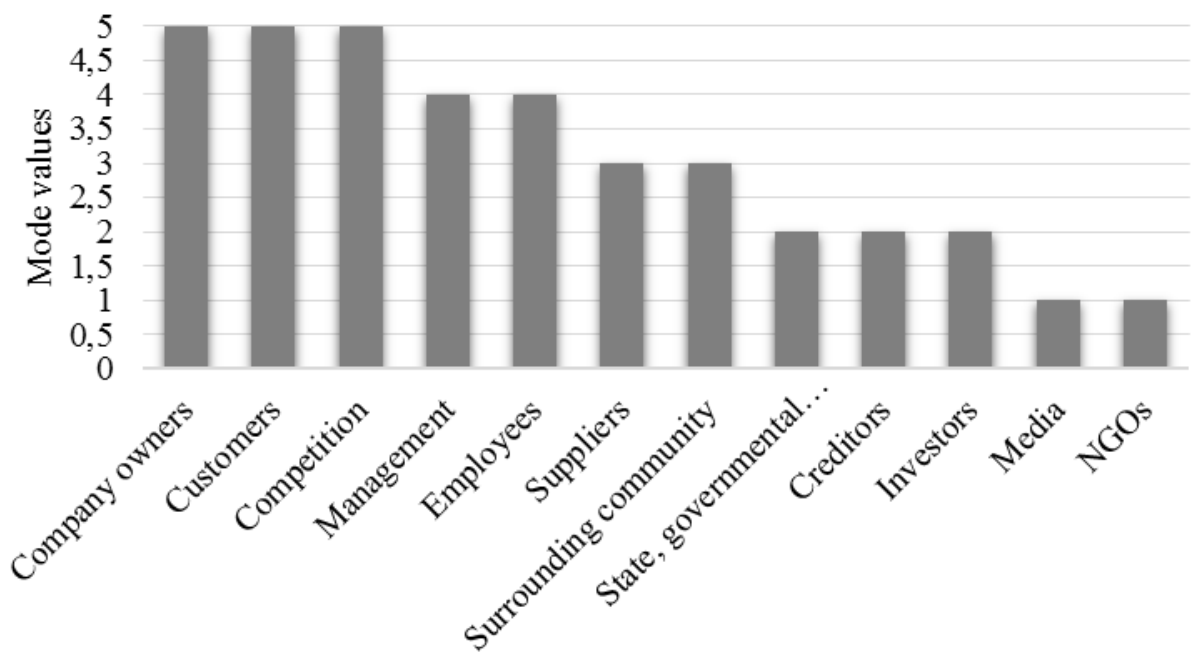

Fig. 3. The importance of stakeholder influence

Source: Own research and processing

The CSR reports provide to a company an opportunity to communicate its CSR efforts to the company's stakeholders and to discuss certain company successes and challenges on a wide array of CSR issues. The CSR report is also a medium for transparency (which often improves a company's reputation with certain stakeholders, particularly shareholders, employees, suppliers and communities within which the company operates) and may be used as an effective outreach tool as part of an ongoing shareholder relations. In addition, the CSR report provides existing and potential investors with CSR information to assist in analyzing investment decisions. From the above mentioned, for companies follows the importance of informing stakeholders about their responsible business and also to choose right or any access to company CSR records.

The purpose of further question was to find out if companies provide annual or special reports in which they inform about their responsible and sustainable marketing activities. For a deeper analysis of the obtained results, there was set out an assumption: „Annual respectively special reports, in which companies inform about sustainable and responsible marketing activities are issued to a greater extent by large companies."

We wanted to find out, if there is dependence between sustainable reporting and the size of the company. We suppose that the activities about which companies would like to inform the general public are activities precisely those companies that dispose with sufficient financial capital and have own department for organization of this activity. We think that smaller companies do not pay too much attention to the issue of such reports and all their resources devote to just the core business performance. Morsing and Perrini argue that the original idea that CSR can afford only strong and rich multinational companies is already overcome because CSR is perceived in a wider context (pillars CSR), which ultimately mean for businesses more savings than 
just the additional costs. The aim of our argument is not that small companies are not oriented towards socially responsible and sustainable activities, but insufficiently inform about these activities and should focus their attention on the area of reporting (sustainable reporting).

This question was tested with the use of Fisher exact test (Tab.4).Degree of dependence is reflected in Table 4 by Phi coefficient, Contingency coefficient and Cramer's coefficient. The values of these coefficients indicate moderate up to strong dependence.

Table 4. Results of Fisher exact test

\begin{tabular}{llll}
\hline Statistic & DF & Value & Prob \\
\hline Chi-Square & 4 & 70,597 & $<.0001$ \\
Likelihood Ratio Chi-Square & 4 & 42,1047 & $<.0001$ \\
Mantel-Haenszel Chi-Square & 1 & 24,1234 & $<.0001$ \\
Phi Coefficient & & 0,767 & \\
Contingency Coefficient & & 0,6086 & \\
Cramer's V & & 0,5424 & \\
\hline
\end{tabular}

\begin{tabular}{lr}
\hline Fisher's Exact Test & \\
\hline Table Probability $(\mathrm{P})$ & $2,45 \mathrm{E}-11$ \\
$\operatorname{Pr}<=\mathrm{P}$ & $9,25 \mathrm{E}-09$ \\
\hline
\end{tabular}

Source: Own processing, XLStat

Based on the results of Fisher exact test, the $\mathrm{H}_{0}$ hypothesis must be on the level of significance $5 \%$ rejected and adopted must be its alternative $\mathrm{H}_{1}$ hypothesis talking about the dependence between the tested variables. In other words, we can conclude that there is a statistical interdependence between issuing of annual/special reports and company size.

To better illustrate, we present graphic processing of the results from questionnaire survey (Fig. 4). As the chart shows, the answer "a" is marked mainly a group of large companies $(82 \%)$, what means that they provide a report, containing information about all responsible marketing activities. $9 \%$ of large companies say they inform partially, and only in requested reports and the same percentage of companies (9\%) argue they do not provide reports about socially responsible and sustainable marketing activities.

An interesting result is apparent when comparing the responses of large companies to micro companies. The percentage structure of responses is almost exactly opposite to responses of large companies. SMCs also do not appear like businesses that regularly issue this kind of reports. In summary we state that $24 \%$ (answer "a" and "b") of SMCs, either regularly or at least partially apply some form of reporting related to sustainable responsible performance. Based on these facts, we can conclude that our scientific assumption was confirmed. 


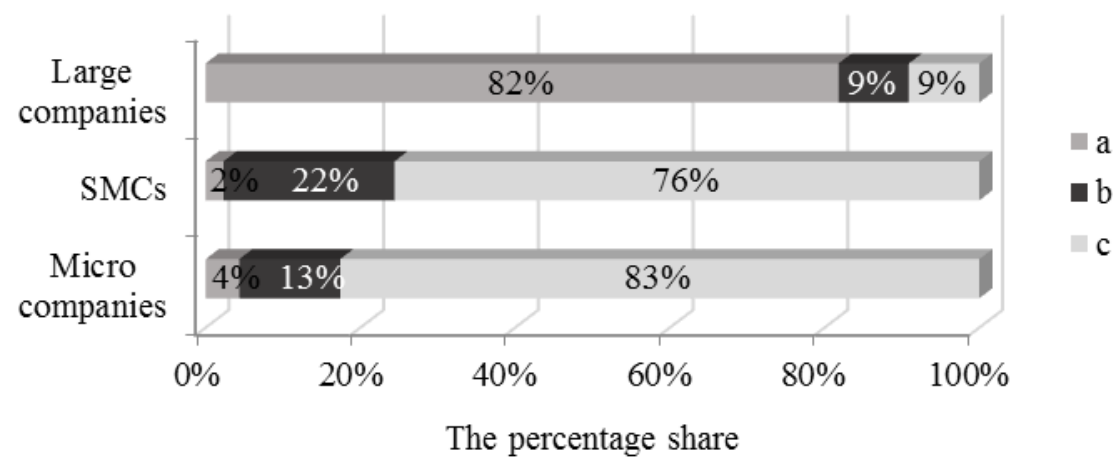

Fig. 4. Issuing of reports - by company size

Source: Own research and processing

\section{Legend:}

a) yes, we provide a report containing information about all marketing activities,

b) partially, we inform about marketing activities in requested reports,

c) no, we do not provide reports about our marketing activities.

\section{Conclusion}

It is obvious that if the potential of social responsibility fully exploited, it cannot become a "prerogative" of large companies, but must become a matter of the whole business sector.

This issue is particularly important in the area of food sector, as these companies are directly or indirectly involved in the production and sale of food products to final customers and provide nutrition of the population. The concept of corporate social responsibility together with applying of sustainable marketing opens new business opportunities. A dialogue with diverse stakeholder groups represents a rich source of ideas for new products, processes or markets, thus contribute to the creation of longterm competitive advantage.

The results showed that among important stakeholders for food companies belong company owners followed by customers, competition, management, employees, suppliers and the surrounding community. The lower values of importance were attributed to stakeholders as state/governmental institutions, creditors, investors, media and NGOs. Food companies should lead effective dialog in great extent with these groups, as they marked them as subjects with the highest degree of influence on their business.

Many authors consider that the original idea that CSR can afford only strong and rich multinational corporations is already overcome. The aim of our argument is not that small businesses are not oriented towards socially responsible and sustainable activities, but insufficiently inform about these activities and should focus their attention on the area of reporting (sustainable reporting). Companies tended to be a little more guarded about providing environmental performance information in light 
of possible penalties and a bad image they may acquire. This trend is likely to change for companies that are interested in moving towards a sustainability report, where all aspects of CSR, including environment, are highlighted in one comprehensive document.

The research confirmed that there are big differences in issuing of reports between different size groups of companies. $82 \%$ of all large companies claim that they provide a report containing information about all responsible marketing activities. 9 $\%$ of large companies say they inform partially and only in requested reports and the same percentage of companies $(9 \%$ ) argue they do not provide reports about socially responsible and sustainable marketing activities. It can be stated that an interesting result is when comparing the responses of large companies to micro companies. The percentage structure of responses is almost exactly opposite to responses of large companies.

In formulating the second assumption we started from a global vision for issuing the reports on the level of sustainable development. Its essence lies in the fact that the administration of comprehensive reports on economic, environmental and social performance of organizations, or even countries, will become so routine matter such as financial reporting and so on. However, the reporting in real practice of industry particularly in small and medium-sized businesses, still faces to several obstacles.

\section{References}

1. Svoboda, J.: Význam konceptu společenské odpovědnosti organizací (CSR) a jeho využívání v České republice. Univerzita Tomáše Bati ve Zlíně, Zlín (2010)

2. Kubicová, L., Kádeková, Z.: Impact of consumer prices and cash income on consumption of dairy products. In: Acta scientiarum polonorum, vol. 12, no. 3, p. 61-71 (2013)

3. Carroll, A.B., Buchholtz, A.: Business and Society: Ethics, Sustainability, and Stakeholder Management. Cengage Learning, USA (2014)

4. Blowfield, M., Googins, B.K.: Step Up: A Call for Business Leadership in Society: CEOs examine role of business in the 21 st century. Boston College Center for Corporate Citizenship, Chestnut Hill (2006)

5. Ubrežiová, I., Kapsdorferová, Z., Sedliaková, I.: Competitiveness of Slovak agri-food commodities in third country markets. In: Acta Universitatis Agriculturae et Silviculturae Mendelianae Brunensis, vol. 60, no. 4 (2013)

6. Weiss, J.W.: Business Ethics: A Stakeholder and Issues Management Approach. Cengage Learning, Mason (2009)

7. Sedliaková, I., Lenčéšová, L.: Corporate culture as a competitive tool. In: Drive your knowledge be a scientist. Tomas Bata University in Zlín, Zlín (2012)

8. Sakál, P. et al.: Udržatel'né spoločensky zodpovedné podnikanie. Alumni Press, Trnava (2013)

9. Zelený, J.: Environmentálne manažérstvo a spoločenská zodpovednost' (organizácií). Univerzita Mateja Bela, Banská Bystica (2008)

10. Jankajová, E., Kotus, M., Holota, T, Zach, M.: Risk Assessment of Handling Loads in Production Process. In: Acta Universitatis Agriculturae et Silviculturae Mendelianae Brunensis, vol. 64, no. 2 (2016)

11. Steinerová, M.: Koncept CSR v praxi: průvodce odpovědným podnikáním. Aspra, Praha (2008), http://www.spolecenskaodpovednostfirem.cz/wp-content/uploads/2013/09/ Konc ept \%20C SR\%20v\%20praxi.pdf 
12. Franc, P., Nezhyba, J., Heydenreich, C.: Když se bere společenská odpovědnost vážně. Ekologický právní servis, Brno (2006), http://www.eps.cz/sites /default/files/ publikace/kdyz se bere csr vazne.pdf.

13. TRNKOVÁ, J.: Společenská odpovědnost firem: kompletní průvodce tématem \& závěry z průzkumu v C̆R (2004), http://www.csr-online.cz/co-je-csr/kam-pro-vice-informaci/

14. Smernice reportovania trvalo udržatelného rozvoja, https://www.globalreporting.org/ resourcelibrary/Slovakian-G3-Reporting-Guidelines.pdf

15. Sustainability Reporting Guidelines, https://www.globalreporting.org/resourcelibrary/ G3.1- Guidelines-Incl-Technical-Protocol.pdf

16. European Commission, http://ec.europa.eu/growth/smes/business-friendly-environment/ sme-definition/index_en.htm 